\title{
Antiproliferation Activity and Apoptotic Mechanism of Soursop (Annona muricata L.) Leaves Extract and Fractions on MCF7 Breast Cancer Cells
}

\author{
Yuni Elsa Hadisaputri (D) 1,2 \\ Ummi Habibah (iD) ${ }^{1,2}$ \\ Fajar Fauzi Abdullah 2,3 \\ Eli Halimah (D) \\ Mutakin Mutakin' \\ Sandra Megantara' \\ Rizky Abdulah iD' \\ Ajeng Diantini ${ }^{\prime}$ \\ 'Faculty of Pharmacy, Universitas \\ Padjadjaran, Jatinangor, West Java, 45363, \\ Indonesia; ${ }^{2}$ Central Laboratory, \\ Universitas Padjadjaran, Jatinangor, West \\ Java, 45363, Indonesia; ${ }^{3}$ Department of \\ Chemistry, Faculty of Mathematic and \\ Sciences, Universitas Padjadjaran, \\ Jatinangor, West Java, 45363, Indonesia
}

\begin{abstract}
Introduction: Breast cancer is the second most common cancer in women globally, and the incidence rate has increased annually. Traditional medicine is frequently used as a cancer treatment, and soursop or Annona muricata L (A. muricata) is a traditional medicinal plant that has been widely used as an anticancer treatment and requires more thorough study.

Methods: In this research, we prepared ethanol extract and three solvents, ie, ethyl acetate, $n$-hexane and water fractions of $A$. muricata leaves and assessed their antiproliferation and cytotoxic activity on MCF7 breast cancer cells compared with that on CV1 normal kidney cells; observation of cell morphology by stained with mixture of propidium iodide and 4',6-diamidino-2-phenylindole indicated that this treatment induced an ongoing process of apoptotic cell death in MCF7 cells. To clarify the cell death mechanism via apoptosis, we assessed the $m R N A$ expression in the caspase cascade of caspase-9, caspase-3, and PARP-1, and anti-apoptotic, $B c l-2$ which mediated cytotoxic activity of extracts and ethyl acetate fractions of $A$. muricata leaves against MCF7 cells.

Results: The ethanol extract, ethyl acetate, $n$-hexane, and water fractions of $A$. muricata leaves had $\mathrm{IC}_{50}$ values of 5.3, 2.86, 3.08, and $48.31 \mu \mathrm{g} / \mathrm{mL}$, respectively, in MCF7 cells but had no activity in CV1 cells. The high cytotoxic activity of $A$. muricata leaves was reflected by changes in the morphology of cancer cells that appeared after $6 \mathrm{~h}$ exposure to A. muricata leaf extract and ethyl acetate fraction; the membrane and nucleus of cells undergoing apoptosis were characterized by the rupture and loss of membranes and nuclei. The mechanism that mediates this cytotoxic activity in MCF7 cells was mediated through a decrease in the expression of $B c l-2 m R N A$ and an increase in caspase- 9 and caspase-3 $m R N A$ expression. Conclusion: Therefore, the leaves of the medicinal plant $A$. muricata contained compounds that on extraction exerted a highly effective activity as an anticancer treatment for breast cancer via induced apoptotic cell death.
\end{abstract}

Keywords: soursop, Annona muricata L., MCF7 breast cancer cell, cytotoxicity, caspasecascade

\section{Introduction}

Cancer comprises a large group of diseases where the rapid growth of abnormal cells can exceed the body's immune defenses, eventually leading to metastasis, which is the main cause of death from cancer. ${ }^{1}$ Breast cancer is the second most common cancer in the world with 2.09 million cases and is by far the most common cancer in women, causing 626,700 deaths in $2018 .^{2}$ In the Asia-Pacific region, the number of deaths from breast cancer is 116,000 , of which Indonesia accounts for $17 \%$ or around 19,720 people. $^{3}$ 
Treatment for breast cancer uses several methods including surgery, chemotherapy, and radiation. However, each method has a weakness, and the success rates for treatments have remained low, even when using anticancer drugs for chemotherapy. Failure in chemotherapy treatment can often occur because of the low selectivity of anticancer drugs and the cancer cell resistance to chemotherapy agents. Cases of drug resistance are encountered with many anticancer drug treatments of cancers such as breast, colon, prostate, and leukemic. ${ }^{4}$ Anticancer drugs generally target cells that are actively proliferating, and therefore, these can cause adverse side effects, especially in highly proliferative tissues and in gastrointestinal systems. $^{5}$

Soursop, Annona muricata L. (A. muricata), which is commonly known as Graviola in Latin America, has been shown to contain promising compounds that can be used in cancer treatment. A. muricata grows in the tropical and subtropical regions of the world, and extracts of this plant contain compounds that are highly effective against cancer cells. ${ }^{6-8}$ Research on A. muricata plant extracts has indicated an antiviral effect $^{9}$ and antiparasitic, antiinflammatory, ${ }^{10}$ and antihyperglycemic properties. Additionally, previous studies found that A. muricata plant extracts were effective against drug-resistant cancer cells. ${ }^{11}$

A. muricata is a member of the family Annonaceae. Plant contains acetogenin in the leaves, stems, fruits, and roots. Acetogenins are fatty acid derivatives that contain 32 to 34 carbon chains that terminate in 2-propanol, which forms methyl gamma lactones at the end of the structure. Additionally, between one and three tetrahydrofurans (THF) rings and a variety of hydroxyl, acetyl, and/or ketoxyl groups can be found along the hydrocarbon chain. ${ }^{12}$

Acetogenin has been identified to have cytotoxic ability, ${ }^{13}$ and in vivo studies have demonstrated the efficacy of acetogenin across a range of activities, ${ }^{11}$ including antitumor, pesticide, antihelmintic, antiviral, antimalarial, and antimicrobial. ${ }^{14}$ The presence of flavonoids along with acetogenin as an active substance in $A$. muricata provides additional benefits to enable maximum therapeutic effects. ${ }^{15}$ Flavonoids are also known to have anticancer activities. Several plants that have polyphenol compounds such as quercetin and flavone flavonoids (2-phenyl-4H-1-benzopyran-4-one) are believed to have chemopreventive properties by reducing the incidence of many types of cancer. ${ }^{6}$
Extracts of A. muricata leaves have been tested on human breast cancer cells, including $\mathrm{MCF} 7,{ }^{7} \mathrm{MDA}$ MB231, ${ }^{6}$ and MDA-MB345S. ${ }^{8}$ A study by Moghadamtousi et $\mathrm{al}^{8}$ demonstrated that the ethyl acetate fraction from A. muricata leaves had the highest cytotoxicity against MCF7 and MDA-MB-231 cells in the 3-(4,5-dimethylthiazol-2-yl)-2,5-diphenyltetrazolium bromide (MTT) assay after $72 \mathrm{~h}$ incubation $\left(\mathrm{IC}_{50}\right.$ ranged from $5.09 \pm 0.41$ to $11.36 \pm 0.67 \mu \mathrm{g} / \mathrm{mL}$ ). The cell death induced by an anticancer agent is programmed cell death or apoptosis. This is an important physiological process that is responsible for homeostatic mechanisms and maintenance of cell populations in tissues. ${ }^{16}$ The intervention of Bax and $\mathrm{Bcl}-2$ protein expression is an important factor for determining tumor susceptibility to a given anticancer agent. ${ }^{17}$ Anticancer research has also shown that the activation of the nuclear factor-kappa B transcription factor is involved in regulating tumor development that promotes malignant and hemopoietic. ${ }^{18}$

This study aimed to clarify the cytotoxic effect of A. muricata leaf extract and fractions using MCF7 breast cancer cells compared with effects on CV1 non-cancerous kidney cells and to confirm A. muricata leaf extract induced MCF7 cell death via cell staining. Moreover, we assessed mRNA expression levels to clarify the molecular mechanism of MCF7 cell death through apoptosis induced by treatment with A. muricata leaf extract and ethyl acetate fractions.

\section{Materials and Methods}

\section{Extract of Annona muricata L. Leaves}

Annona muricata L. (A. muricata) leaves were dried under a net in sunlight. The extract was prepared via the maceration method where up to $3.1 \mathrm{~kg}$ of $A$. muricata leaves was extracted with up to $50 \mathrm{~L}$ of $70 \%$ ethanol. After $24 \mathrm{~h}$, the liquid extract was collected. The solvent was then evaporated with a rotary evaporator at $45^{\circ} \mathrm{C}$. The extract was concentrated using a freeze dryer (Arayukro, Gimpo, South Korea) at a temperature of $-80^{\circ} \mathrm{C}$ to obtain a thick total extract. The yield of extract was calculated as (weight of extract $[\mathrm{g}] /$ weight of dried of $A$. muricata leaves $[\mathrm{g}]) \times 100$.

\section{Fractionation of Annona muricata L. Leaf Extract}

Approximately $30 \mathrm{~g}$ of A. muricata leaf extract was dissolved in $500 \mathrm{~mL}$ of water. The extract solution was poured into a separating funnel, and an $n$-hexane solvent was added with the same volume as the water (1:1). First, 
the $n$-hexane phase was collected and then added back to the same volume of $n$-hexane solvent in the water phase. A rotary evaporator was used to obtain a thick fraction from the solvent. The water phase from the fractionation with $n$-hexane was returned to a separating funnel, and ethyl acetate was added with the same volume (1:1). The ethyl acetate phase was collected and then added back to the same volume of ethyl acetate solvent in the water phase. A rotary evaporator was used to obtain a thick fraction from the solvent. The water phase obtained from ethyl acetate fractionation was concentrated using a rotary evaporator. All fraction yields were calculated using the formula, yield fraction $=($ weight of fraction obtained $[\mathrm{g}] /$ weight of thick A. muricata leaves extract [g]) $\times 100$.

\section{Thin Layer Chromatography}

To ensure that acetogenins were indeed present in the A. muricata leaf extract and fractions, thin layer chromatography (TLC) was conducted in this study. The samples used were the A. muricata leaf extract and ethyl acetate fraction that had the smallest $\mathrm{IC}_{50}$ value. TLC used a comparison of the $n$-hexane:ethyl acetate (2:8) mobile phase. Sample solution was spotted onto silica gel 60 GF254 TLC plate of $1 \times 7 \mathrm{~cm}$ (Sigma Aldrich; Merck KGaA, Darmstadt, Germany). Spots were observed under ultraviolet light $\lambda=254$ and $366 \mathrm{~nm}$. $\mathrm{AlCl}_{3}$ and Ehrlich solutions were used to visualize all the spots on the plate. Flavonoid compounds fluoresce with a yellow-green color after being sprayed with $\mathrm{AlCl}_{3}$, whereas the acetogenin compound has a pink color when sprayed with Ehrlich reagents and after heating. The retention factor (Rf) value was calculated by the formula $\mathrm{Rf}=$ the distance from the starting point to the center of the spot on the TLC plate/the distance from the starting point to the solvent front.

\section{Cell Culture}

The MCF7 breast adenocarcinoma, CV1 normal kidney to represent non-cancerous cell, A549 lung carcinoma dan HeLa cervical cancer cell lines were purchased from the American Type Culture Collection. MCF7 cells were cultured in Eagle's Minimum Essential Medium (EMEM) (Sigma Aldrich; Merck KGaA), CV1 and A549 cells were cultured in RPMI 1640 medium (Gibco), while HeLa cells were cultured in Dulbecco's Modified Eagle Medium (Sigma Aldrich; Merck KGaA); All of medium were supplemented with 10\% fetal bovine serum (Sigma Aldrich; Merck KGaA) and $100 \mathrm{U} / \mathrm{mL}$ penicillin and
$100 \mu \mathrm{g} / \mathrm{mL}$ streptomycin (Sigma Aldrich; Merck KGaA). Cells were cultured in a $\mathrm{CO}^{2}$ incubator with $5 \% \mathrm{CO}^{2}$ at $37^{\circ} \mathrm{C}$. Media was replaced once every 2 days. The cell condition was checked every day using an IX53 Inverted Microscope (Olympus Corp, Tokyo, Japan).

\section{Cell Proliferation Test}

Cytotoxicity of $A$. muricata leaf extract and $n$-hexane, ethyl acetate, and water fractions was tested on the MCF7 breast cancer cell line, and extract and ethyl acetate fractions were assessed with CV1 cells; both tests used the 3-(4,5-dimethylthiazol-2-yl)-5-(3-carboxymethoxyphenyl)-2-(4-sulfophenyl)-2H-tetrazolium (MTS) assay. Cell viability was determined using CellTiter $96^{\circledR}$ AQueous One Solution Cell Proliferation Assay (Promega Corp, Madison, Wisconsin, USA) based on the manufacturer's instructions. A range of concentrations of $A$. muricata leaf extract and fractions at $0.97,3.9,15.6,62.5$, and $250 \mu \mathrm{g} /$ $\mathrm{mL}$ were dissolved in 10\% dimethyl sulfoxide (Sigma Aldrich; Merck KGaA) solvent. Cell suspension (50 $\mu \mathrm{L}$, $1.6 \times 10^{6}$ cells) was added to each well of a 96-well plate (Falcon, Franklin Lakes, NJ, USA), which was incubated at $37^{\circ} \mathrm{C}$ for 24 h. A. muricata leaves extract samples and fractions were added to separate wells, and the plate was incubated at $37^{\circ} \mathrm{C}$ for 24 and $48 \mathrm{~h}$. The absorbance was read at $490 \mathrm{~nm}$ using an Infinite M200 PRO microplate reader (Tecan, Männedorf, Switzerland). The value of cell proliferation inhibition $(\mathrm{CPI})$ rate $(\%)$ was calculated with the formula: CPI rate $(\%)=\left(1-\mathrm{OD}_{490}\right.$ of the untreated cells) $\times 100$.

\section{Cell Colony Assay}

MCF7 cells were added at 500 cells per cell culture flask and incubated for $24 \mathrm{~h}$. Cells were treated with samples of $A$. muricata leaf extract or ethyl acetate fraction at 0 , 5, 10, and $25 \mu \mathrm{g} / \mathrm{mL}$. Each test was conducted in triplicate and was then re-incubated for 10 days until there were at least 50 cells in each individual colony. During the incubation period, $10 \mathrm{~mL}$ of EMEM (Sigma Aldrich; Merck $\mathrm{KGaA}$ ) media was replaced every 3 days. The cells formed were stained using $2.5 \mathrm{~mL}$ Giemsa dye (Wako, Osaka, Japan), incubated for $30 \mathrm{~min}$ at room temperature, and then washed with running water. ${ }^{18}$ The number of colonies that had been formed was counted using an IX53 Inverted Microscope (Olympus Corp). The survival rate of colonies (\%) was calculated with the following formula: survival rate $(\%)=$ (number 
of colonies formed after treatment/number of colonies formed without treatment) $\times 100$.

\section{Staining Test for MCF7 Breast Cancer Cells}

Cells were plated and incubated for $24 \mathrm{~h}$. Cells were then treated in triplicate with $A$. muricata leaf extract samples or ethyl acetate fractions together with negative controls. The concentration of A. muricata leaf extract sample and ethyl acetate fraction was adjusted according to each $\mathrm{IC}_{50}$ concentration; 5.3 and $2.86 \mu \mathrm{g} / \mathrm{mL}$. Cells were incubated for $6 \mathrm{~h}$ in a $\mathrm{CO}^{2}$ incubator and rinsed with a phenol-free medium carefully at room temperature. Up to $200 \mu \mathrm{L}$ of a mixture of 4',6-diamidino-2-phenylindole (DAPI) (Sigma Aldrich; Merck KGaA) and propidium iodide (PI) (Sigma Aldrich; Merck KGaA) was added, and incubation was continued at room temperature without light for $20 \mathrm{~min}^{7}$ Following this, cells were observed under fluorinated ZEISS Apotome.2 (Carl Zeiss, Germany) microscopes using Cy3 and DAPI filters.

\section{RNA Extraction and Polymerase Chain Reaction (PCR)}

RNA was isolated from cells exposed to extract or ethyl acetate fraction of A. muricata leaves at 0,12 , and $24 \mathrm{~h}$. A Miniprep ${ }^{\circledR}$ Directzol RNA kit (Zymo Research, CA, USA) was used to isolate RNA. The Reverse Transcriptase PCR (RT-PCR) reaction was completed using Labcycler thermal cycler (SensoQuest, Göttingen, Germany) according to the manufacturer's instructions. The quantity of isolated RNA was measured using the A260/A280 ratio with an Infinite M200 PRO multimode microplate reader (Tecan) and a GelPilot ${ }^{\circledR}$ DNA loading dye (Qiagen, Hilden, Germany) kit according to the manufacturer's instructions. All primers were purchased from Macrogen Inc. (Seoul, South Korea) with the specifications as shown in Table 1 with 35 cycles of amplification. The results were quantified via electrophoresis and band density calculation. The mRNA expression from target genes was quantified by the image processing program, ImageJ ver. $1.53 \mathrm{e}(\mathrm{NIH}$, Bethesda, MD, USA). Each sample was tested at least three times.

\section{Statistical Analysis}

Data are presented as an average \pm standard deviation of each group data. The statistical assessment for mRNA expression was conducted using IBM SPSS statistic 25
Table I Temperature Optimization for Each Primer

\begin{tabular}{|l|l|l|l|}
\hline Primer & & Sequences & $\mathbf{T}^{*}\left({ }^{\circ} \mathbf{C}\right)$ \\
\hline Caspase-9 & $\begin{array}{l}\text { Forward } \\
\text { Reverse }\end{array}$ & $\begin{array}{l}\text { 5'-AAGTGACCCTCCCAAGTAGC-3' } \\
\text { 5'-GTTCTGGCCAGGTCTCTTCT-3' }\end{array}$ & 60.5 \\
\hline Caspase-3 & $\begin{array}{l}\text { Forward } \\
\text { Reverse }\end{array}$ & $\begin{array}{l}\text { 5'-AAAATACCAGTGGAGGCCGA-3' } \\
\text { 5'-GCACAAAGCGACTGGATGAA-3' }\end{array}$ & 58.4 \\
\hline PARP-1 & $\begin{array}{l}\text { Forward } \\
\text { Reverse }\end{array}$ & $\begin{array}{l}\text { 5'-TGGAACATCAAGGACGAGCT-3' } \\
\text { 5'-CATCGCTCTTGAAGACCAGC-3' }\end{array}$ & 60.5 \\
\hline Bcl-2 & $\begin{array}{l}\text { Forward } \\
\text { Reverse }\end{array}$ & $\begin{array}{l}\text { 5'-TCCTCTTTACACTGGCCAGG-3' } \\
\text { 5'-GAGTATTTGTGCAGCGAGGG-3' }\end{array}$ & 60.5 \\
\hline GAPDH & $\begin{array}{l}\text { Forward } \\
\text { Reverse }\end{array}$ & $\begin{array}{l}\text { 5'-AAGGTGAAGGTCGGAGTCAAC-3' } \\
\text { 5'-CTTGATTTTGGAGGGATCTCG-3' }\end{array}$ & 57.3 \\
\hline
\end{tabular}

Note: ${ }^{*}$, annealing temperature.

(IBM Corp., NY) assessed by One way ANOVA and Tukey post hoc test. A P value of $<0.05$ was considered statistically significantly different.

\section{Results}

\section{Extraction and Fractionation of}

\section{A. muricata Leaves and Acetogenin Detection}

The yield of the extract obtained from approximately $3.1 \mathrm{~kg}$ of $A$. muricata leaves was $17.01 \%$ at $527.39 \mathrm{~g}$. We used $155 \mathrm{~g}$ of $A$. muricata leaf extract for fractionation and obtained fraction yields of $0.5 \%(0.761$ g), $19.01 \%$ (26.074 g), and $85 \%$ (116.548 g) for the $n$-hexane, ethyl acetate, and water fractions, respectively. A TLC test pattern of the A. muricata extract using $n$-hexane:ethyl acetate $(2: 8)$ produced five spots. The spot with a $\mathrm{Rf}$ value $=0.4$ (Supplementary Table 1$)$ indicated the presence of an acetogenin compound. The evidence for the presence of acetogenin was further strengthened by TLC results that showed spots from the ethyl acetate fraction of A. muricata leaves at a $\mathrm{Rf}$ value $=0.4$ (Supplementary Table 1), which had a pink-red color with $\mathrm{AlCl}_{3}$ solution and a pink color with Ehrlich solution (Supplementary Figure 1).

\section{Ethyl Acetate Fraction Had the Most Effective Inhibitory Activity of MCF7 Cells Proliferation}

We assessed the inhibitory activity of samples for $24 \mathrm{~h}$ against MCF7 and CV1 cells. The best $\mathrm{IC}_{50}$ values for the A. muricata leaf extract obtained against MCF7 breast cancer cells were from $5.3 \mu \mathrm{g} / \mathrm{mL}$ ethanol extract, 
Table $2 \mathrm{IC}_{50}$ Values $24 \mathrm{~h}$ of A. muricata Leaves Extract, and It's Fractions; ie, Ethyl Acetate, $n$-Hexane, and Water Fraction on MCF7 and CVI Cells

\begin{tabular}{|l|c|c|}
\hline \multirow{2}{*}{ Sample } & \multicolumn{2}{|c|}{ IC $_{50}(\mu \mathrm{g} / \mathrm{mL})$} \\
\cline { 2 - 3 } & MCF7 & CVI \\
\hline Extract & 5.3 & n.d.* \\
Ethyl acetate fraction & 2.86 & n.d.* \\
n-Hexane fraction & 3.08 & n.d.* \\
Water fraction & 48.31 & n.d.* \\
\hline
\end{tabular}

Abbreviations: $*_{n}$.d, not determined.

whereas ethyl acetate, $n$-hexane, and water fractions produced effective $\mathrm{IC}_{50}$ values at 2.86, 3.08, and $48.31 \mu \mathrm{g} / \mathrm{mL}$, respectively. The ethyl acetate fraction against MCF7 cells had the most effective inhibitory ability with an $\mathrm{IC}_{50}$ value of $2.86 \mu \mathrm{g} / \mathrm{mL}$ and did not have any cell inhibitory effect on CV1 cells (Table 2). The graph of $A$. muricata leaves extract and fractions proliferation assay results is shown in Figure 1. A. muricata leaves extract and ethyl acetate fractions also assessed on A549 and HeLa cell proliferation ability after treatment for $48 \mathrm{~h}$ (Supplementary Table 2).

\section{Cell Colony Assay}

Figure 2 shows the results of the cell colony assay for MCF7 breast cancer cell treated with $A$. muricata extract.
Higher concentrations of the $A$. muricata leaf extract had an inverse reciprocal effect on colony formation, and the survival rate of the colony decreased with increased concentration. Meanwhile, the results of the colony assay on cells treated with ethyl acetate fraction of $A$. muricata leaf did not survive and forming a colony, so that the data could not be graphed and displayed.

\section{Observation of Morphology Cells Treated with A. muricata Leaf Extract and Ethyl Acetate Fraction}

Cell changes were observed after $6 \mathrm{~h}$ of treatment with A. muricata leaf extract and ethyl acetate fraction. Cell appeared to bleb and rupture into smaller parts (Figure 3B and C) compared with untreated cells (Figure 3A); this cell morphology change is related to apoptosis and the process of cell death. In Figure $3 \mathrm{~B}$ and $\mathrm{C}$, the cell apoptosis process occurred in MCF7 cells with $A$. muricata leaf extract and fractions of ethyl acetate treatment depended on the $\mathrm{IC}_{50}$ values. The cytotoxic activity of $A$. muricata leaves could be demonstrated by observing the morphology of cancer cells undergoing apoptosis. Cell treatment with the ethyl acetate fraction of $A$. muricata leaves resulted in the membranes and nuclei of cells undergoing apoptosis at a faster rate than that in the control as

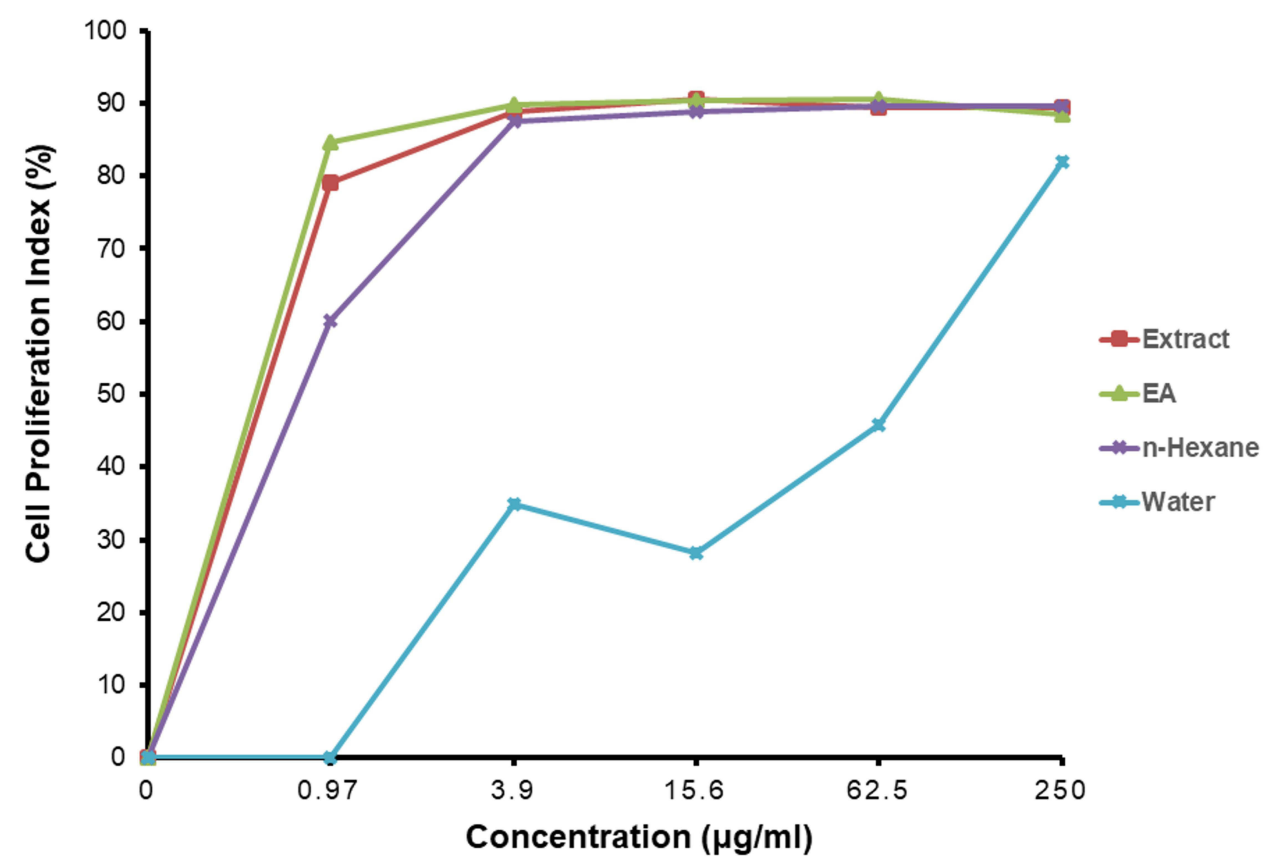

Figure I A. muricata L. extract and fractions, ie, ethyl acetate, $n$-hexane and water, effect on MCF7 cells proliferation. MCF-7 cells treated in various concentrations of A. muricata L. for $24 \mathrm{~h}$. Data are presented as mean \pm standard deviation. 


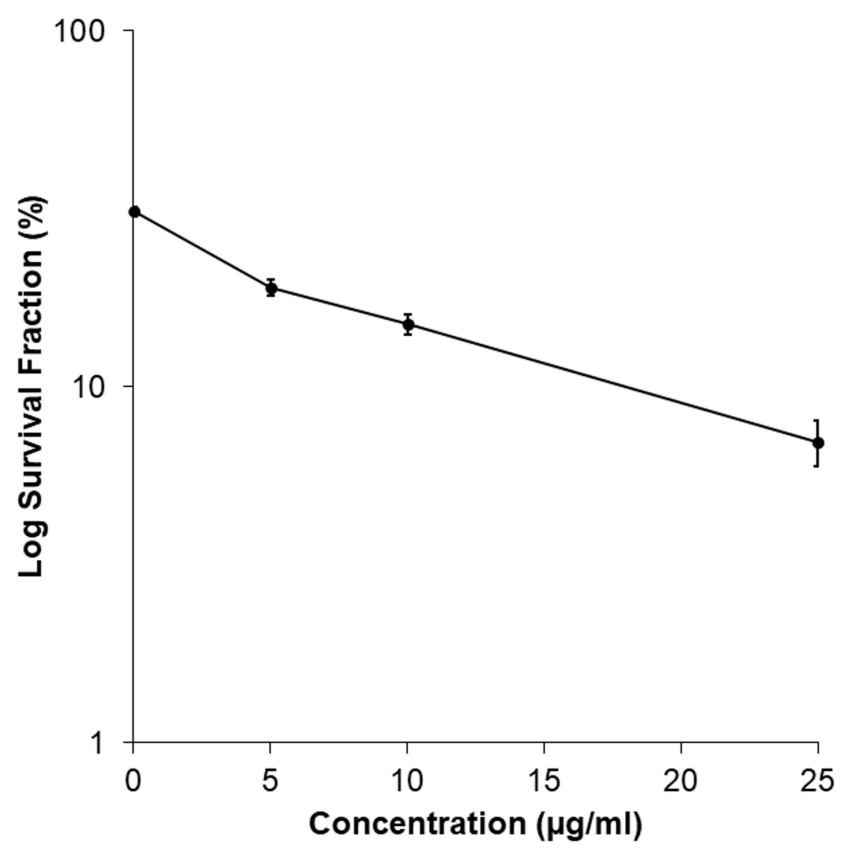

Figure 2 Effect of the A. muricata L. Extract on Colony formation of MCF7 cells. The survival rates of colonies were determined by various concentrations of A. muricata $L$ extract. The higher concentration of $A$. muricata $L$. extract were exposed is $25 \mu \mathrm{g} / \mathrm{mL}$, the less the MCF7 cell colonies are formed with \% survival $22.5 \%$. Whereas MCF7 cells which treated with ethyl acetate fraction of $A$. muricata leaves were not found to form colonies.

characterized by cell rupture and loss of membrane and cell nucleus integrity (Figure 3C).

\section{PCR and Electrophoresis}

We used PCR to assess the molecular effect of $A$. muricata leaf extract and ethyl acetate fraction on MCF7 cells (Figure 4). Expression of apoptosis was analyzed in MCF7 cells that were treated with both the A. muricata leaf extract and ethyl acetate fraction, bands shown in Figure 4A. This was assessed by measuring the expression of caspase-3, caspase-9, PARP-1, and Bcl-2, at 0, 12, and $24 \mathrm{~h}$ incubation; GAPDH was used as a control. A. muricata lead extract induced initiator caspase expression, as shown by a significant increase in expression of caspase-9 mRNA ( $\mathrm{P}=0.001$ for both $12 \mathrm{~h}$ and $24 \mathrm{~h})$ in MCF7 cells, which was followed with increasing expression of executor caspase, caspase-3, after $24 \mathrm{~h}(\mathrm{P}=0.001)$ treatment. $P A R P-1$ expression significantly increased by 12 $\mathrm{h}(\mathrm{P}=0.001)$ but was suppressed at $24 \mathrm{~h}(\mathrm{P}=0.001)$, whereas $\mathrm{Bcl}-2$ expression was significantly decreased at 12 $(\mathrm{P}=0.001)$. The expression of caspase- 9 significantly decreased after $12(\mathrm{P}=0.001)$ and $24 \mathrm{~h}(\mathrm{P}=0.001)$ in MCF7 cells treated with $A$. muricata ethyl acetate fraction. Expression of caspase-3 $m R N A$ was significantly increased at $12 \mathrm{~h}(\mathrm{P}=0.004)$ in MCF7 cells treated with $A$. muricata ethyl acetate fraction, whereas expression of PARP-1 $m R N A$ increased at $12 \mathrm{~h}(\mathrm{P}=0.001)$ then decreased at 24 $\mathrm{h}(\mathrm{P}=0.001)$. At the same time, expression of $\mathrm{Bcl}-2$ $m R N A$ decreased significantly at both $12(\mathrm{P}=0.001)$ and $24 \mathrm{~h}(\mathrm{P}=0.001)$ (Figure 4B).

\section{Discussion}

The effectiveness of chemotherapy as a cancer treatment is limited because of adverse side effects and the development of chemoresistance. ${ }^{19}$ One plant that may be used as an anticancer agent is $A$. muricata, which has long been used as traditional medicine. ${ }^{10}$ Acetogenin, one of the compounds in A. muricata, has strong cytotoxic activity and is believed to have a role in killing cancer cells. ${ }^{20,21}$ Here, we used a CPI assay to assess the antiproliferation effect against MCF7 cells using various concentrations of ethanol extract, and ethyl acetate and water fractions of A. muricata indicated to have strong cytotoxic activity against MCF7 cells (Table 2), that is stronger than activity against A549 and HeLa cells (Supplementary Table 2). The results of $\mathrm{CPI}_{50}$, the minimum concentration of inhibition, indicating that a lower level of ethyl acetate fraction at $2.86 \mu \mathrm{g} / \mathrm{mL}$ was more effective than $5.3 \mu \mathrm{g} / \mathrm{mL}$ of A. muricata leaf extract. This concentration was comparable with that used in the induction of apoptosis in MCF7 cells treated for a short period of time using the ethyl acetate fraction. Morphological changes of MCF7 cells (Figure 2) were also observed for $6 \mathrm{~h}$ after being treated with ethyl acetate fraction.

Based on phytochemical screening results, compounds detected in ethanol extract of $A$. muricata leaves include flavonoids, alkaloids, cardiac glycosides, tannins, triterpenoids, saponins, and reducing sugars. ${ }^{22}$ Aqueous extracts and fractions of $A$. muricata leaves contain alkaloids, terpenoids, flavonoids, coumarin, steroids, fatty acids, phenols, tannins, and saponins, whereas the ethyl acetate fraction contains phenols, saponins, tannins/polyphenols, and flavonoids. ${ }^{23}$ A. muricata leaves also contain more than 45 acetogenins in the leaves and seeds. ${ }^{24}$ Identification of acetogenin can be visualized using TLC by the development of pinkish purple-colored spots. ${ }^{24}$ In this study, TLC used the ethanol extract and fraction of ethyl acetate $A$. muricata leaves with an $n$-hexane:ethyl acetate mix (2:8) (Supplementary Figure 1D) and obtained a $\mathrm{Rf}$ value of 0.4 and with a pink-red color after spraying with Ehrlich reagent. Ehrlich reagent spray can be used to detect the presence of compounds that have furan groups 
A

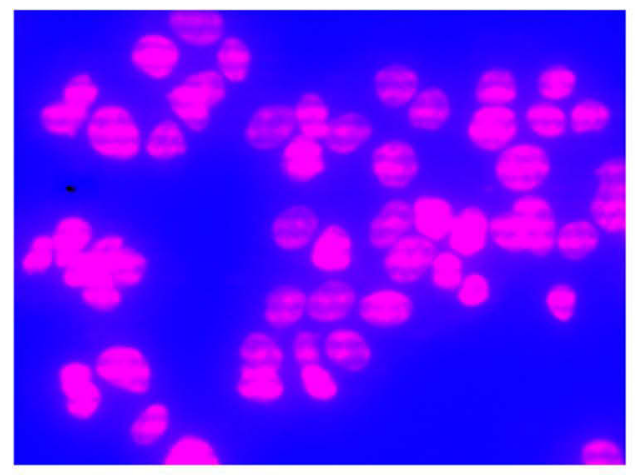

C
B

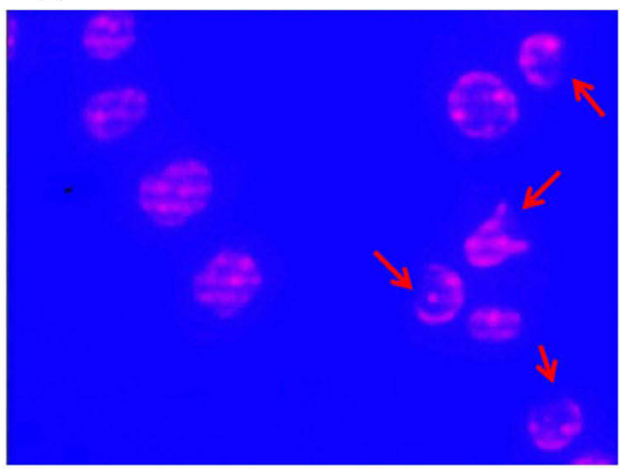

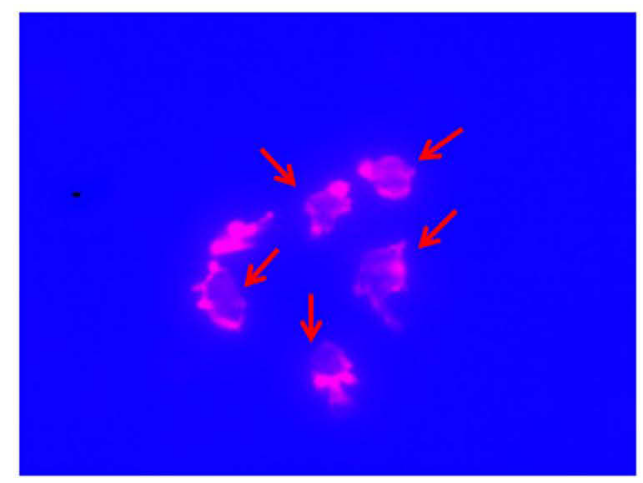

Figure 3 Changes of MCF7 cells form figure. (A) MCF7 cells were exposed extracts of A. muricata L. for 0 h; (B) MCF7 cells after treated with A. muricata L. Extract for 6 h; (C) MCF7 cells after treated with A. muricata L Ethyl acetate fraction for $6 \mathrm{~h}$. MCF7 cells observed under fluorinated ZEISS Apotome.2 (Carl Zeiss, Germany) microscopes with Cy3 and DAPI filters. MCF7 cells form after treatment with A. muricata L. either extracts or ethyl acetate fractions to be inconsistent and rupture to parts (indicated by a red arrow).

such as those present in the structure of acetogenin to produce a red color. $^{25}$

Based on the level of cytotoxicity, $\mathrm{IC}_{50}$ values are divided into three levels including strong $(<100 \mu \mathrm{g} / \mathrm{mL})$, moderate $(101-200 \mu \mathrm{g} / \mathrm{mL})$, and weak $(>201 \mu \mathrm{g} / \mathrm{mL}),{ }^{26}$ A. muricata leaves extract and fractions cytotoxicity level is strong. In another study, increased concentrations of A. muricata leaf extract significantly induced a decrease in viability of MDA-MB-231 and MCF7 breast cancer cells; ${ }^{20,21}$ the ethyl acetate fraction of $A$. muricata leaves was also significantly cytotoxic against several MCF7 and MDA-MB-231 cancer cells with $\mathrm{IC}_{50}$ values of 6.39 and $11.36 \mu \mathrm{g} / \mathrm{mL}$, respectively. ${ }^{8}$ Similarly, we obtained $\mathrm{IC}_{50}$ values in the range of 2.86 to $48.31 \mu \mathrm{g} / \mathrm{mL}$ with samples of $A$. muricata extract and ethyl acetate, $n$-hexane, and water fractions, indicating that these have strong cytotoxic activity against MCF7 breast cancer cells (Table 2). The ethyl acetate fraction has a very high toxic value compared with other samples, with an $\mathrm{IC}_{50}$ value of $2.86 \mu \mathrm{g} / \mathrm{mL}$. This may be caused by phenols, saponins, tannins/polyphenols, and flavonoids within this fraction ${ }^{22}$ and, in particular, acetogenin and flavonoids, which are major toxic compounds. ${ }^{21,27}$ Factors that affect the concentration of active compounds in $A$. muricata may include elements of soil compounds and treatments used to grow A. muricata. Overall, the extracts and fractions of A. muricata leaves exhibited cytotoxicity toward breast cancer cells in a dose-dependent manner and suppressed cell proliferation. To assess the safety of the compounds contained in A. muricata, the effect on the proliferation of non-cancerous CV1 cells was assessed. The results in Table 2 show that the $\mathrm{IC}_{50}$ value of $\mathrm{CV} 1$ cells treated with $A$. muricata leaf extract and fractions could not be determined, indicating that these are not toxic or inhibitory to non-cancerous cell proliferation. Therefore, the compounds contained in A. muricata leaves have selective inhibitory properties on cancer cells that have a high proliferation rate.

The clonogenic assay also confirmed these results by determining anticancer activity after exposure to the A. muricata extract and ethyl acetate fraction over an extended period; this assay assessed the effect of test 
A

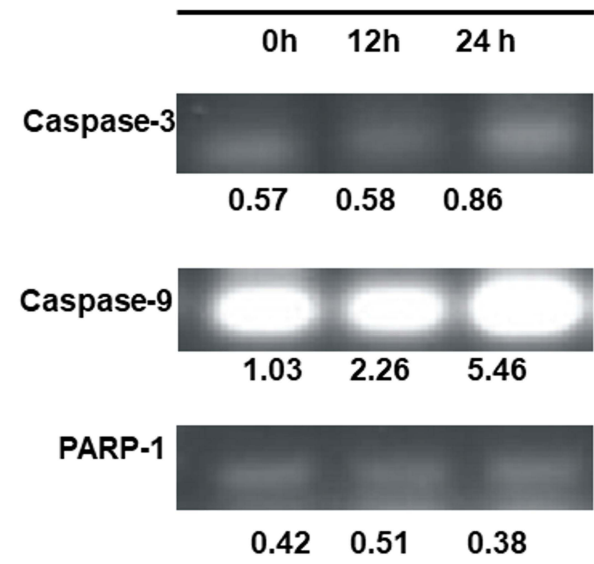

Bcl-2
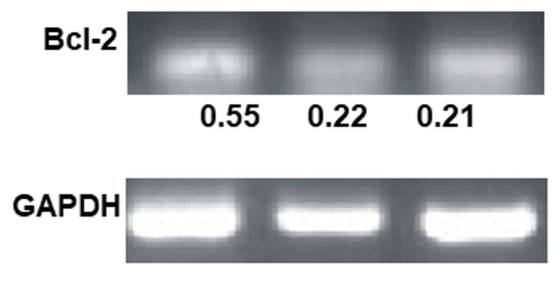

B

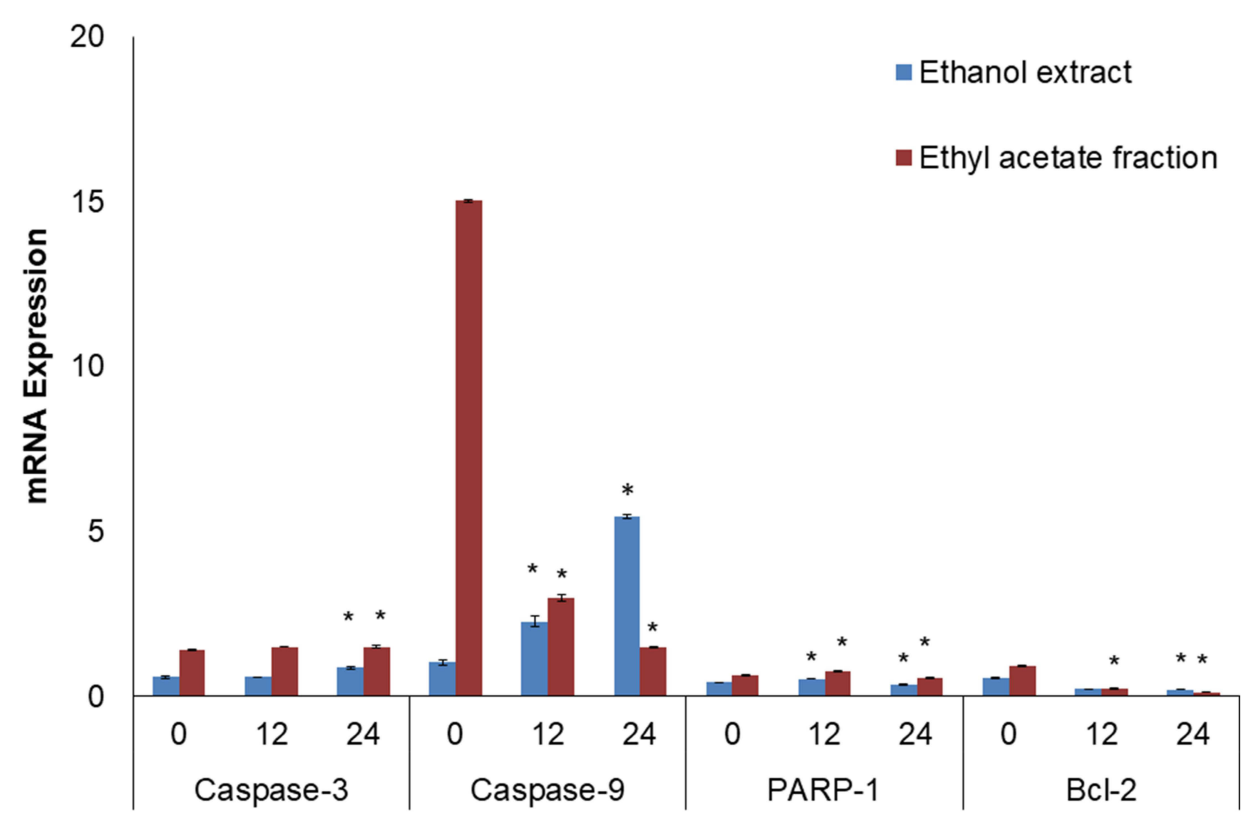

Observation time (h)

\section{Ethyl acetate fraction}

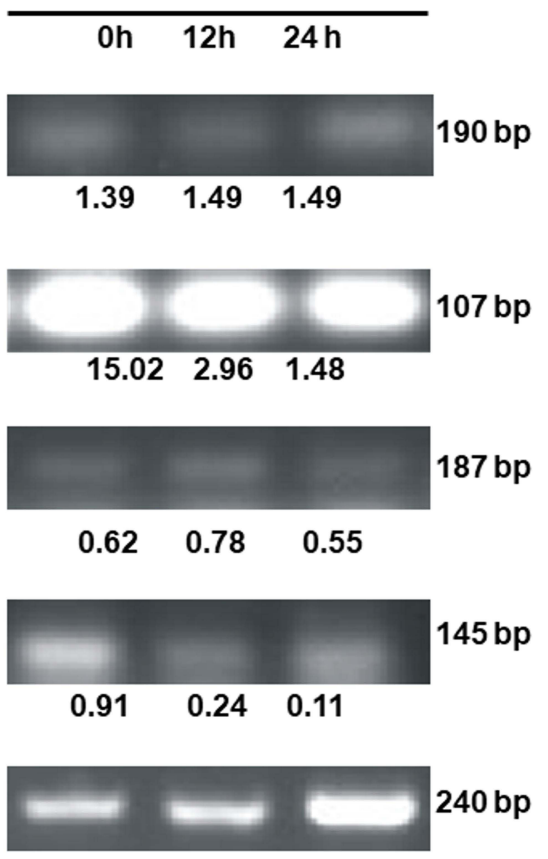


samples with extended time on human breast cancer cells and their ability to form colonies. ${ }^{28}$ Cancer cells were unable to form colonies and were characterized by a decreased survival rate with increasing treatment concentration (Figure 2). In another study, treating cells with A. muricata leaf extract reduced the number of colonies formed; the number of which substantially decreased with increasing extract concentration. ${ }^{20,21}$ Previous study has reported a good correlation with in vivo testing of tumorigenicity, ${ }^{11}$ where the cancer clonogenicity results were reduced depending on the concentration after exposure. $^{28}$

We observed MCF7 cancer cell morphology using microscopy with DAPI staining to determine whether cell nucelli were undergoing apoptosis and compared this with staining using PI, which cannot penetrate cell membranes and is used to dye necrotic cell DNA. ${ }^{29}$ The morphology of MCF7 cells indicated that these were apoptotic as demonstrated by the fragmentation of the nucleus, constricted cytoplasm, and formed apoptotic bodies. ${ }^{30}$ Apoptosis was observed in MCF7 cells that were treated with $A$. muricata leaf extract and ethyl acetate fraction and that induced morphological changes where the MCF7 cell membrane and cell nucleus were seen to rupture and disintegrate (Figure 3B and C). When treated with the ethyl acetate fraction, the apoptotic form was dis-ordered, and the cell membranes and nuclei start to disappear, whereas with ethyl acetate extract treatment, the cell membrane appears to undergo apoptosis; however, a number of cells still maintain their normal shape. Thus, the compounds contained in the A. muricata plant have a very high cytotoxic ability as indicated by the small $\mathrm{IC}_{50}$ value and an apoptotic morphology at $6 \mathrm{~h}$ incubation with the ethyl acetate fraction, which had higher cytotoxic and apoptotic abilities than that of the $A$. muricata leaf extract (Figure 3C).

The apoptotic process induction mechanism of acetogenin blocks the production of Adenosine triphosphate (ATP) in the mitochondria of cancer cells so that the energy supply is interrupted and cancer cells become weak until cell death occurs. ${ }^{31}$ Acetogenin reduces ATP production by inhibiting the NADH: ubiquinone oxidoreductase (Complex I) in the electron transport system in mitochondria and ubiquinone that is associated with NADH oxidase in tumor cell plasma membranes ${ }^{32}$ that lead to induce the process of apoptosis. ${ }^{31}$ The lactone ring contained in the acetogenin molecule has an important role in the anticancer mechanism. Annonacin is known as the most common acetogenin present in $A$. muricata leaves and most of the acetogenin contained in A. muricata contains a THF ring. ${ }^{24}$ Additionally, acetogenin induces apoptosis by inhibiting the expression of Bcl-2 and Bcl-xL antiapoptotic proteins, enabling the increase of expression of Bax and Bad pro-apoptotic proteins, ${ }^{33}$ and also increasing expression of caspase $3 / 7$ and caspase 9 at mRNA and protein levels. $^{34}$ In this study, the expression of Bcl-2 mRNA decreased after treatment with $A$. muricata leaf extract and ethyl acetate fraction. These results indicate that the decrease in Bcl-2 protein expression has an important role in inducing apoptosis in MCF7 cells, where the mechanism of apoptosis activates caspase- 9 as an initiator of apoptosis ${ }^{35}$ and caspase- 3 as one of the apoptotic executors. ${ }^{36}$ Here, we characterized the molecular changes in MCF7 cells that were affected by exposure to A. muricata leaf extract and ethyl acetate fraction for up to $24 \mathrm{~h}$. Both $A$. muricata leaf extract and ethyl acetate fraction induced MCF7 cells to enter apoptosis, but there was a difference in apoptotic-related gene expression (Figure 4). Broadly speaking, in MCF-7 cells treated with $A$. muricata leaf extract, the expression of caspase9 and $-3 m R N A$ significantly increased, whereas that of $B c l-2$ expression significantly decreased; there was no significant increase in expression of PARP-1 $m R N A$, indicating that the apoptotic process was not finished yet. A different phenomenon occurred in MCF7 cells treated with the ethyl acetate fraction, where expression of caspase- 9 and $-3 m R N A$ did not increase, but the expression of PARP-1 $m R N A$ started to decrease, whereas that of expression of $\mathrm{Bcl}-2$ expression did significantly decrease. This indicated that the apoptotic process occurred faster in MCF7 cells treated with the ethyl acetate fraction of A. muricata leaves than that treated with the ethanol extract. This result supports the observed morphological changes that indicated that apoptosis occurred when MCF7 cells were treated with the ethyl acetate fraction with cell rupture and loss of cell membranes and nuclei at $6 \mathrm{~h}$ incubation (Figure 3). The Bcl-2 protein affects the permeability of the mitochondrial membrane and will affect the release of cytochrome c. Decreased expression of Bcl-2 will result in the induction of apoptosis as the mitochondrial release of cytochrome $\mathrm{c}$ is no longer inhibited, and this then activates the caspase pathways to produce caspase- 3 as apoptotic executors. ${ }^{35}$

Overall, a wide range of phytochemicals can be extracted from A. muricata, which include acetogenin; the synergistic effects of these phytochemicals may be the underlying 
principle behind the chemotherapeutic potential of A. muricata. Extrinsic apoptosis testing needs to be explored and further testing completed to identify the active substances involved in anticancer effects.

\section{Conclusions}

In conclusion, the treatment of breast cancer cells using the $A$. muricata leaf ethyl acetate fraction produced a higher level of cytotoxicity that was responsible for the antiproliferation activity than the A muricata leaf extract; this was enabled through a significant reduction in the integrity of mitochondrial membranes that resulted in the induction of apoptosis of breast cancer cells. The apoptotic mechanism can be seen from changes in cell morphology and in the expression of Bcl-2, caspase-9, and caspase-3 $m R N A$ that mediate the cytotoxic activity of the ethyl acetate fraction of $A$. muricata leaf on MCF7 cells.

\section{Abbreviations}

A. muricata, Annona muricata Linn; $\mathrm{IC}_{50}$, inhibitor concentration $50 \%$; THF, tetrahydrofuran; NF- $\kappa \mathrm{B}$, nuclear factorkappa B; TLC, thin layer chromatography; Rf, retention factor; MTS, 3-(4,5-dimethylthiazol-2-yl)-5-(3-carboxymethoxyphenyl)-2-(4-sulfophenyl)-2H-tetrazolium; MTT, 3-(4,5-dimethylthiazol-2-yl)-2,5-diphenyltetrazolium bromide; DMSO, Dimethyl sulfoxide; CPI, cell proliferation inhibition; DAPI, 4',6-diamidino-2-phenylindole; PI, propidium iodide; RT, Reverse Transcriptase; PCR, polymerase chain reaction; ATP, Adenosine triphosphate.

\section{Acknowledgments}

The authors would like to thank Professor Unang Supratman, M.Si., Ph.D. (Central Laboratory, Universitas Padjadjaran), for providing all the necessary facilities to carry out the present work. The authors would also like to thank Ms. Kusmiati, S.Si. (Central Laboratory, Universitas Padjadjaran), for her excellent technical support and assistance. This study was supported by grant-in-aids from The Indonesian Ministry of Research, Technology, and Higher Education Grant No: 718/UN6.3.1/PL/2017, for AD. Mr. Fajar Fauzi Abdullah has completed his studies and is now working at the Department of Chemistry, Faculty of Mathematics and Natural Sciences, Universitas Garut.

\section{Disclosure}

Ms Ummi Habibah reports Higher Education Grant from the Indonesian Government during the conduct of the study and outside the submitted work. The authors report no other potential conflicts of interest in this work.

\section{References}

1. Faubert B, Solmonson A, DeBerardinis RJ. Metabolic reprogramming and cancer progression. Science. 2020;368(6487):eaaw5473. doi:10.1126/science.aaw5473

2. Ferlay JR, Colombet M, Soerjomataram I, et al. Estimating the global cancer incidence and mortality in 2018: GLOBOCAN sources and methods. Int J Cancer. 2019;144:1941-1953. doi:10.1002/ijc.31937

3. Youlden DR, Cramb SM, Yip CH, Baade PD. Incidence and mortality of female breast cancer in the Asia-Pacific region. Cancer Biol Med. 2014;11:101-115. doi:10.7497/j.issn.2095-3941

4. Jayaraj R, Nayagam SG, Kar A, et al. Clinical theragnostic relationship between drug-resistance specific miRNA expressions, chemotherapeutic resistance, and sensitivity in breast cancer: a systematic review and meta-analysis. Cells. 2019;8(10):1250. doi:10.3390/cells 8101250

5. Kulmira N, Thomas J, Raquel A. Editorial: adverse effects of cancer chemotherapy: anything new to improve tolerance and reduce sequelae? Front Pharmacol. 2018;9:245. doi:10.3389/fphar.2018. 00245

6. Moghadamtousi SZ, Kadir HA, Elham M, Rouhollahi P, Karimian H. Annona muricata leaves induced apoptosis in A549 cells through mitochondrial-mediated pathway and involvement of NF-kB. $B M C$ Complement Altern Med. 2014;14:299. doi:10.1186/1472-6882-14299

7. Naik AV, Sellappan K. In vitro evaluation of Annona muricata $L$. (Soursop) leaf methanol extracts on inhibition of tumorigenicity and metastasis of breast cancer cells. Biomarkers. 2020;25(8):701-710. doi:10.1080/1354750X.2020.1836025

8. George VC, Kumar DRN, Rajkumar V, Suresh PK, Kumar RA. Quantitative assessment of the relative antineoplastic potential of the n-butanolic leaf extract of Annona muricata Linn. in normal and immortalized human cell lines. Asian Pacific J Cancer Prev. 2012;13:699-704. doi:10.7314/apjcp.2012.13.2.699

9. Morosetti G, Criscuolo AA, Santi F, Perno CF, Piccione E, Ciotti M. Ellagic acid and Annona muricata in the chemoprevention of HPV related pre neoplastic lesions of the cervix. Onco Lett. 2017;13:1880-1884. doi:10.3892/ol.2017.5634

10. Moghadamtousi SZ, Fadaeinasab M, Nikzad S, Mohan G, Ali HM, Kadir HA. Annona muricata (Annonaceae): a review of its traditional uses, isolated acetogenins and biological activities. Int $J$ Mol Sci. 2015;16(7):15625-15658. doi:10.3390/ijms160715625

11. Torres MP, Rachagani S, Purohit V, et al. Graviola: a novel promising natural-derived drug that inhibits tumorigenicity and metastasis of pancreatic cancer cells in vitro and in vivo through altering cell metabolism. Can Lett. 2012;323:29-40. doi:10.1016/j.canlet.2012.03.031

12. Liaw CC, Liou JR, Wu TY, Chang FR, Wu YC. Acetogenins from annonaceae. Prog Chem Org Nat Prod. 2016;101:113-230. doi:10.1007/978-3-319-22692-7_2

13. Chang FR, Liaw CC, Lin CY, Chou CJ, Chiu HF, Wu YC. New adjacent bis-tetrahydrofuran annonaceous acetogenins from Annona muricata. Planta Med. 2003;69:241-246. doi:10.1055/s-2003-38485

14. Yang C, Gundala SR, Mukkavilli R, Vangala S, Michelle DR, Aneja R. Synergistic interactions among flavonoids and acetogenins in graviola (Annona muricata) leaves confer protection against prostate cancer. Carcinogenesis. 2015;36(6):656-665. doi:10.1093/carcin/ bgv046

15. Dinda B, Dinda S, DasSharma S, Banik R, Chakraborty A, Dinda M. Therapeutic potentials of baicalin and its aglycone, baicalein against inflammatory disorders. Eur J Med Chem. 2017;131:68-80. doi:10.1016/j.ejmech.2017.03.004 
16. Kim SS, Cho HJ, Kang JY, Kang HK, Yoo TK. Inhibition of androgen receptor expression with small interfering RNA enhances cancer cell apoptosis by suppressing survival factors in androgen insensitive, late stage Lncap cells. Sci World J. 2013;519397:1-8. doi:10.1155/ 2013/519397

17. Martinou JC, Youle RJ. Mitochondria in apoptosis: bcl-2 family members and mitochondrial dynamics. Dev Cell. 2011;21:92-101. doi:10.1016/j.devcel.2011.06.017

18. Hadisaputri YE, Miyazaki T, Suzuki S, et al. Molecular characterization of antitumor effects of the rhizome extract from Curcuma zedoaria on human esophageal carcinoma cells. Int $J$ Oncol. 2015;47(6):2255-2263. doi:10.3892/ijo.2015.3199

19. Kekre N, Griffin C, Mc Nulty J, Pandey S. Pancratistatin causes early activation of caspase- 3 and the flipping of phosphatidylserine followed by rapid apoptosis specifically in human lymphoma cells. Cancer Chemother Pharmacol. 2005;56:29-38. doi:10.1007/s00280-004-0941-8

20. Kim JY, Dao TTP, Song K, et al. Annona muricata leaf extract triggered intrinsic apoptotic pathway to attenuate cancerous features of triple negative breast cancer MDA-MB-231 cells. Evid Based Complement Alternat Med. 2018;10:2018. doi:10.1155/2018/7972916

21. Romli MF, Hamid M, Alitheen NB, Rahman NMA. Anti-cancer effect of Annona Muricata Linn Leaves Crude Extract (AMCE) on breast cancer cell line. BMC Complement Altern Med. 2016;16 (1):311. doi:10.1186/s12906-016-1290-y

22. Gavamukulya Y, Abou-Elella F, Wamunyokoli F, AEl-Shemy H. Phytochemical screening, anti-oxidant activity and in vitro anticancer potential of ethanolic and water leaves extracts of Annona muricata (Graviola). Asian Pac J Trop Med. 2014;7(Suppl 1):S355-S363. doi:10.1016/S1995-7645(14)60258-3.31

23. Agu KC, Okolie PN. Proximate composition, phytochemical analysis, and in vitro antioxidant potentials of extracts of Annona muricata (Soursop). Food Sci Nutr. 2017;5(5):1029-1036. doi:10.1002/fsn3.498

24. Gleye CP, Duret R. Cis-Monotetrahydrofuran acetogenins from the rots of Annona Muricata. J of Nat Prod. 1998;61:576. doi:10.1021/np970494m

25. Ducheyne P, Heal K, Hutmacher DW, David WG, Kirkpatrick J. Comprehensive Biomaterials II. US: Elsevier; 2017:312.

26. Subarnas A, Diantini A, Abdulah R, et al. Antiproliferative activity of primates-consumed plants against MCF7 human breast cancer cell lines. J Med Res. 2012;1:038-043. doi:10.1016/j.jep.2019.03.003
27. Yang C, Gundala SR, Mukkavilli R, Vangal S, Michelle DR, Ritu A. Synergistic interactions among flavonoids and acetogenins in graviola (Annona muricata) leaves confer protection against prostate cancer. Carcinogenesis. 2015;36(6):656-665. doi:10.1093/carcin/bgv046

28. Kuo PL, Hsu YL, Cho CY. Plumbagin induces G2-M arrest and autophagy by inhibiting the AKT/mammalian target of rapamycin pathway in breast cancer cells. Mol Cancer Ther. 2006;5(12):5. doi:10.1158/1535-7163.MCT-06-0478

29. Afsar T, Janeen HT, Christine ES, Suhail R, Muhammad RK, Ahmed K. Growth inhibition and apoptosis in cancer cells induced by polyphenolic compounds of Acacia hydaspica: involvement of multiple signal transduction pathways. Sci Rep. 2016;6(23077). doi:10.1038/srep23077

30. Moongkarndi P, Kosem N, Kaslungka S, Luanratana O, Pongpan N, Neungton N. Antiproliferation, antioxidation and induction of apoptosis by Garcinia mangostana (mangosteen) on SKBR3 human breast cancer cell line. J Ethnopharmacol. 2004;90:161-166. doi:10.1016/j. jep.2003.09.048

31. Alali FQ, Liu XX, McLaughlin JL. Annonaceous acetogenins: recent progress. J of Nat Prod. 1999;62. doi:10.1021/np980406d

32. Kim J, Park EJ. Cytotoxic anticancer candidates from natural resources. Curr Med Anti Cancer Agents. 2002;2:485-537. doi:10.2174/1568011023353949

33. Yuan SSF, Chang HL, Chen HW, et al. Selective cytotoxicity of squamocin on T24 bladder cancer cells at the S Phase via a Bax-, Bad-, and Caspase-3-related pathway. J Life Sci. 2006;78:869-874. doi:10.1016/j.1fs.2005.05.068

34. Moghadamtousi SZ, Rouhollahi E, Karimian H, et al. The chemopotential effect of Annona muricata leaves against azoxymethane-induced colonic aberrant crypt foci in rats and the apoptotic effect of acetogenin Annomuricin E in HT-29 cells: a bioassay-guided approach. PLoS One. 2015;10:e122288. doi:10.1371/journal.pone.0122288

35. Elmore S. Apoptosis: a review of programmed cell death. Toxicol Pathol. 2007;35:495-516. doi:10.1080/01926230701320337

36. Green DR, Llambi F. Cell death signaling. Cold Spring Harb Perspect Biol. 2015;7:a006080. doi:10.1101/cshperspect. a006080

\section{Publish your work in this journal}

Breast Cancer - Targets and Therapy is an international, peer-reviewed open access journal focusing on breast cancer research, identification of therapeutic targets and the optimal use of preventative and integrated treatment interventions to achieve improved outcomes, enhanced survival and quality of life for the cancer patient.
The manuscript management system is completely online and includes a very quick and fair peer-review system, which is all easy to use. Visit http://www.dovepress.com/testimonials.php to read real quotes from published authors. 